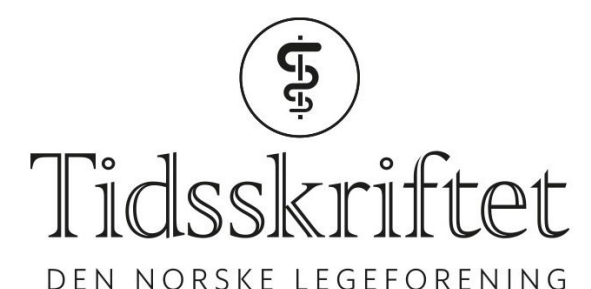

DEN NORSKE LEGEFORENING

\title{
Rettelse: Lavere behandlingsmål for LDL-kolesterol bør innføres
}

RETTELSE

KJETIL RETTERSTøL

JOHN MUNKHAUGEN

CHARLOTTE BJÖRK INGUL

JOSTEIN GRIMSMO

ANNE KASK

HENRIK SCHIRMER

ANNE GRETE SEMB

ERIK EKKER SOLBERG

Tidsskr Nor Legeforen 2021; 141: 122-4.

I Tidsskriftet nr. 2/2021, s. 124 skal det stå: Charlotte Björk Ingul er dr.med., spesialist i hjertesykdommer og overlege ved LHL-sykehuset Gardermoen. Forfatteren har fylt ut ICMJE-skjemaet og oppgir følgende interessekonflikter: Hun har mottatt honorar fra Bayer.

Vi beklager feilen, den er rettet på nett.

Publisert: 22. februar 2021. Tidsskr Nor Legeforen. DOI: 10.4045/tidsskr.21.0096

(C) Tidsskrift for Den norske legeforening 2020. Lastet ned fra tidsskriftet.no 